\title{
Physical Properties of Chilli Sauce as Affected by Different Concentration of Water Yam's Starch
}

\author{
Ulyarti $^{1}$, Surhaini ${ }^{1}$, Nazarudin ${ }^{1,2}$, Lisani ${ }^{1}$, Astrini $\mathrm{Y}^{1}$ \\ ${ }^{1}$ Departement of Agricultural Product Technology \\ Faculty of Agricultural Technology, University of Jambi, Indonesia \\ ${ }^{2}$ Departement of Chemical Engineering \\ Faculty of Engineering, University of Jambi, Indonesia \\ E-mail:ulyarti@unja.ac.id
}

\begin{abstract}
The aim of this research was to determine the effect of purple water yam's starch concentration on the physical properties of chili sauce. This study used a completely randomized design consisted of 5 levels concentration of purple water yam's starch (0, 1, 2, 3 and $4 \%$ ) and four replications. ANOVA showed that the concentration of purple water yam's starch significantly affected the sauce viscosity and syneresis but did not affect the aroma and color of the sauce. Among the levels of starch concentration used as treatment, the concentration of $2 \%$ purple water yam's starch produced chilli sauce with the best physical properties with viscosity of 48.75 Poise and syneresis $2.14 \%$.
\end{abstract}

Keywords- purple water yam; starch; chilli sauce; physical properties

\section{INTRODUCTION}

Water yam (Dioscorea alata) locally in Jambi Province of Indonesia is known as "uwi", "umbi arang" or "ubi kelapa". The tuber of water yam contains high carbohydrate with starch as the main component. There is challenge in extracting starch from the tuber of water yam due to its high content of mucus. The mucus interferes in the extraction process causing starch is unable to be extracted. Among purple, yellow, and white tuber, yellow tuber of water yam produced the highest yield of starch [1]. However, yellow tuber produced starch with low lightness value (L*) and yellowish color. Starch from purple water yam tuber had high lightness value $\left(\mathrm{L}^{*}\right)$ and white in color [2].

Water yam's starch is known to have good pasting properties to be used as thickening agent [3]. The ability of water yam starch to thicken tomato sauce for example, depended on the concentration of starch. The higher the concentration the thicker the sauce texture. However, the use of high concentration of starch decreased the stability of the sauce viscosity during storage [3]. Similar to tomato sauce, viscosity and stability are the main quality parameter for chilli sauce in conjuction with spiciness level [4]. Therefore in this experiment, several concentration of purple water yam's starch were used to determine the effect of starch concentration on physical properties of chilli sauce, in particular the viscosity and stability. Some sensory properties such as texture (thickness/viscosity), color and aroma were also examined to obtain a more complete investigation.

\section{MAterial AND MethodS}

\section{A. Material}

The fresh purple water yam's tubers were harvested at District of Sungai Lumpur, Bangko in Province of Jambi. Red chillies and tomato of apple variety were harvested at Kerinci,
Province of Jambi. The other materials included salt, acetic acid, sugar, garlic and water.

\section{B. Research Design}

The experiment was carried out using complete random design with 5 level of starch concentration and 4 replication. The starch concentration of $0,1,2,3$, and $4 \%$ were calculated based on the weigh of final chilli pulp after addition of all ingredients.

\section{Methods}

\section{Starch Extraction}

Purple water yam's starch was extracted using method in our previous study [2]. The tubers were previously washed, peeled and rewashed using running tap water before sliced into $2 \mathrm{~mm}$ to $3 \mathrm{~mm}$ thick. The slices were further soaked in $15 \%$ table salt solution for 30 minutes and rewashed for 3 times. These procedures were carried out to remove mucus and obtain more starch. The tuber slices were smoothed using commercial blender and the slurries were passed through 200 mesh filter. The suspension obtained were precipitated for 6 hours. The sediment was redissolved in water and reprecipitated to purify the starch. This procedure was repeated for four times until the colorless supernatant was obtained. The wet starch was dried in air-oven dryer at $50^{\circ} \mathrm{C}$ for 6 hours. The dry starch was sieved using 60 mesh filter, sealed packaged and kept at room temperature until further used.

\section{Chilli Sauce Processing}

The sortation was carried out at the beginning of the process that only chillies with optimum maturity and without physical defects were processed. Similar process was carried out for tomato. Only tomatoes with $90 \%$ or more redness were used for chilli sauce processing. For every 300 gram 
chillies needs 90 gram tomatoes. Both chillies and tomatoes were clean to remove the stalks and blanched at $80^{\circ} \mathrm{C}$ for 3 minutes. After cooling, both chillies and tomatoes were smoothed using commercial blender with addition of $900 \mathrm{ml}$ water. Sugar (36 g), garlic (10 g) and salt (10 g) were added to this chilli paste, cooked at $100^{\circ} \mathrm{C}$ for 30 minutes, cooled to $50^{\circ} \mathrm{C}$, and $\mathrm{pH}$ adjusted to 3.5 using $25 \%$ acetic acid. The starch as thickening agent was added at this point depend on the level of the treatment. The sauce was reheated at $80^{\circ} \mathrm{C}$ for 10 minutes before packaged in sterile jar.

\section{Chilli Sauce Analysis}

Viscosity of chilli sauce was determined using Rion viscotester VT-04 [5] and trained panelists [6]. Measurements of viscosity using viscotester were taken twice after 3 days (initial viscosity) and after 30 days of storage at room temperature. About $200 \mathrm{ml}$ of chilli sauce was placed in the $250 \mathrm{ml}$ beaker glass. The spindle was placed in the middle of the sauce and set for $6 \mathrm{rpm}$ speed. Reading can be taken directly from the scale.

Sensory evaluation for viscosity used pair comparison test with 5 scale: thicker than Ref; nearly thicker than Ref; as thick as Ref; nearly thinner than Ref; thinner than Ref. Commercial chilli sauce was used as reference.

Stability of chilli sauce was determined using measurement of syneresis [7]. Thirty gram of chilli sauce was placed in a plastic cup with a lid and stored at room temperature for 30 days. The water leak from the sauce was separated and weighed. Syneresis is presented as percentage of water leak out of chilli sauce.

Color and aroma of chilli sauce were also determined with pair comparison test using trained panelists [6]. The scale for color: more red than Ref; nearly more red than Ref; as red as Ref; nearly less red than Ref; less red than Ref. The scale for aroma: stronger than Ref; nearly stronger than Ref; as strong as Ref; nearly not strong than Ref; not strong than Ref. Commercial chilli sauce was used as reference.

\section{RESULT AND DISCUSSION}

\section{A. Viscosity}

Purple water yam's starch concentration significantly affected viscosity of chilli sauce determined using both viscotester and trained panelists (Table 1). Chilli sauce viscosity was well-noticed by the panelists when compared to control chilli sauce, even at the lowest concentration of purple water yam's starch. At similar starch concentrations, the viscotester was failed to distinguished their viscosities.

As seen in Table 1, starch concentration higher than $2 \%$ produced marked increased in sauce viscosity. However, the concentration that produce viscosity same as reference chilli sauce (scale 3 ) is in the range of $2-3 \%$. The viscosity relates to the amount of water available in the system. Water yam's starch absorbs water in the sauce system during heating. The heating is continued until starches fully gelatinised. This gelatinisation process helps the starch to perform its thermoplastic properties and produce thickness in the sauce. As long as water is available, the higher starch concentration increases the amount of swollen starch granules and hence increases the sauce viscosity.

Starch concentration also affected viscosity after 30 days of storage. The higher starch concentration, more unstable the viscosity during storage. The explanation for this is correlated with syneresis as explained below.

\section{B. Syneresis}

Syneresis or serum separation is a parameter for stability of sauce viscosity during storage. Leakage of water from a gel is a normal phenomenon for chilli sauce even without starch as thickening agent [4]. The addition of proper type and amount of starch could minimize the degree of syneresis. As seen in Table 1, the addition of purple water yam starch for $1 \%$ produced no syneresis after 30 days storage, however this amount of starch did not produce desirable viscosity, either. The higher starch concentration in chilli sauce increased the degree of syneresis which in turn decreased sauce viscosity during storage. The proper concentration for purple water yam starch will be in between $2 \%$ and $3 \%$ in order to produce desired sauce viscosity, but with syneresis. Further modification in chilli sauce processing or modification in purple water yam starch is needed to obtain the desired viscosity wthout syneresis. Homogenization may be one alternative modification of chilli sauce processing as homogenization may prevent separation between small and larger particles in sauce system [8].

TABLE 1

Physical and Sensory Properties of Chilli Sauce Using Different Concentration Of Purple Water Yam's Starch

\begin{tabular}{ccccccc}
\hline $\begin{array}{c}\text { Starch } \\
\text { Concentration (\%) }\end{array}$ & $\begin{array}{c}\text { Initial Viscosity } \\
\text { (Poise) }\end{array}$ & $\begin{array}{c}\text { Viscosity after 30 } \\
\text { days (Poise) }\end{array}$ & $\begin{array}{c}\text { Sensory evaluation } \\
\text { for Viscosity* }\end{array}$ & $\begin{array}{c}\text { Syneresis } \\
(\%)\end{array}$ & $\begin{array}{c}\text { Color } \\
* *\end{array}$ & $\begin{array}{c}\text { Aroma } \\
* * *\end{array}$ \\
\hline 4 & $242.5 \mathrm{a}$ & $110.0 \mathrm{a}$ & $4.72 \mathrm{a}$ & $5.84 \mathrm{a}$ & $3.78 \mathrm{a}$ & $4.00 \mathrm{a}$ \\
3 & $87.50 \mathrm{~b}$ & $81.25 \mathrm{~b}$ & $4.11 \mathrm{~b}$ & $3.41 \mathrm{~b}$ & $3.78 \mathrm{a}$ \\
2 & $48.75 \mathrm{c}$ & $40.75 \mathrm{~cd}$ & $2.78 \mathrm{c}$ & $2.14 \mathrm{c}$ & $3.83 \mathrm{a}$ & $3.94 \mathrm{a}$ \\
1 & $42.50 \mathrm{c}$ & $42.50 \mathrm{c}$ & $2.89 \mathrm{c}$ & 0 & $\mathrm{~d}$ & $3.89 \mathrm{a}$ \\
0 & $37.25 \mathrm{c}$ & $33.75 \mathrm{~d}$ & $2.11 \mathrm{~d}$ & 0 & $\mathrm{~d}$ & $4.89 \mathrm{a}$ \\
\hline
\end{tabular}

Means with the same letter in the same column are not significantly different $(p>0.05)$

*Scale: 5: Thicker than Ref; 4: nearly thicker than Ref; 3: as thick as Ref; 2: nearly thinner than Ref; 1: Thinner than Ref

** Scale : 5:more red than Ref; 4:nearly more red than Ref; 3:as red as Ref; 2:nearly less red than Ref; 1:less red than Ref

*** Scale : 5:stronger than Ref; 4:nearly stronger than Ref; 3:as strong as Ref; 2:nearly not strong than Ref; 1:not strong than Ref. 


\section{REFERENCES}

\section{Color and Aroma}

Color is one characteristics which contributes to the acceptance of chilli sauce [4]. The presence of reference chilli sauce from nasional brand during sensory evaluation helped the panelist to evaluate color and aroma of chilli sauce samples, with the assumption that consumers prefer redness and strong chilli aroma in the reference chilli sauce. Table 1 showed that the redness and strong chilli aroma of chilli sauce were not affected by the concentration of purple water yam starch. This can be understood because the starch was odorless. The maximum starch concentration used in this experiment was also too little to make a change in sauce color.

\section{CONCLUSION}

Purple water yam starch was succesfully used as thickening agent in the processing of chilli sauce with some imperfection that the sauce undergo serum separation and decrease in viscosity during storage. The use of $2 \%$ starch was found to be insufficient to produce desired viscosity, but the use of 3\% starch was a little higher that it produced nearly thicker sauce than reference sauce.
[1] Nadia, L., Hartati. 2011. Potensi umbi uwi ungu sebagai bahan pangan dan khasiatnya sebagai pangan fungsional. Laporan Penelitian. Universitas Terbuka, Jakarta

[2] Ulyarti, Lavlinesia, Fortuna, D., \& Surhaini. 2016. The study of physical properties of Dioscorea alata's starch from Jambi Province. IJASEIT , 456-459.

[3] U Ulyarti, L Lavlinesia, N Nuzula, N Nazarudin. 2018. Sifat fungsional pati ubi kelapa kuning (Dioscorea alata) dan pemanfaatannya sebagai pengental pada saus tomat. Agritech 38 (3): 235-242

[4] Rengsutthi K \& Charoenrein S. 2011. Physico-chemical properties of jackfruit seed starch (Artocarpus heterophyllus) and its application as thickener and stabiliser in chilli sauce. LWT - Food Science and Technology 44:1309-1313.

[5] Susanto, T \& Yuwono, S. 2001. Pengujian Fisik Pangan. Unesa Press. Surabaya.

[6] Soekarto, S. T. 1985. Penilaian Organoleptik Untuk Industri Pangan dan Hasil Pertanian. Bhratara Karya Aksara, Jakarta

[7] Masbanto. 2001. Pengaruh Penambahan Konsentrasi Karagenan Bubuk terhadap Karakteristik Gel Cincau Hitam Bubuk. Skripsi. Surabaya: Unika Widya Mandala Surabaya.

[8] Bayod, E., WIllers, E., \& Tornberg, E. (2008). Rheological and structural characterization of tomato paste and its influence on the quality of ketchup. $L W T, 1289-13000$ 